\title{
The Migration of Peoples from the Caribbean to the Bahamas
}

Grace Turner

William \& Mary

Follow this and additional works at: https://scholarworks.wm.edu/aspubs

\section{Recommended Citation}

Turner, G. (2013). The Migration of Peoples from the Caribbean to the Bahamas. Nieuwe West-Indische Gids, 87(1/2), 254.

This Article is brought to you for free and open access by the Arts and Sciences at W\&M ScholarWorks. It has been accepted for inclusion in Arts \& Sciences Articles by an authorized administrator of W\&M ScholarWorks. For more information, please contact scholarworks@wm.edu. 
The Migration of Peoples from the Caribbean to the Bahamas. Keith L. Tinker. Gainesville: University Press of Florida, 2011. x + 199 pp. (Cloth US\$ 69.95)

Keith Tinker should be commended for tackling the complex topic of Caribbean migration to the Bahamas. He used a wide array of evidence, including colonial government documents, newspapers, books, and interviews with both immigrants and a few Bahamians. Lingering tensions and sensitivities are reflected in the fact that some interviewees, even decades later, requested anonymity for fear of reprisals or negative feedback.

The only previous book on this topic is The Haitian Problem: Illegal Migration to the Bahamas, published in 1979, by Dawn Marshall. Tinker constantly references this work regarding more recent Haitian migration. He outlines historical circumstances affecting "sending societies" for the largest numbers of immigrants. These include Barbados, Jamaica, Turks \& Caicos Islands, Guyana, and Haiti. Two chapters are devoted to Haiti because of its long history of Bahamian immigration.

As for the "receiving society," there is no in-depth treatment of circumstances within the Bahamas even though this was done for the "sending societies." The introduction and Chapter 2, on migration to the Bahamas to 1888 , were likely intended for this purpose but neither one effectively illustrates conditions after emancipation. Readers glean details about life in the Bahamas from six chapters examining experiences of Caribbean immigrants.

For the postemancipation period Tinker uses sweeping statements that present a skewed perspective of the experience of Bahamians of African descent. He states, "The post-Emancipation period witnessed a search for a more secure economic base... Some Bahamians produced agricultural and marine products... Others, however, including many young black men, migrated to Florida, Central, and South America in search of improved employment opportunities" (p. 3). He does not specify when this migration by young black Bahamian men occurred. Before emancipation in the United States in 1865 there was no motivation for black Bahamians, no matter how economically oppressed, to migrate there. It was certainly an option for white Bahamians, and these were the earliest Bahamian emigrants to Florida. The $185^{2}$ quote from Governor Rawson W. Rawson demonstrated that the British colonial administration advised black Bahamians against emigrating to the southern United States simply because "Her Majesty's 
free black and Coloured subjects [were] not admitted to the enjoyment within the Southern States of the Union in full and free participation in the privileges and civil rights enjoyed by Her Majesty's white subjects" (p. 34).

Tinker only vaguely acknowledges the role of the British colonial administration on migration among its West Indian territories. Chapter 1 outlines historical migration trends for African-descended populations within the British Caribbean, but the Bahamas is never situated within this regional colonial perspective. It is not coincidental that Caribbean migration to the Bahamas, except for Haiti, was generally from other British colonial territories.

Issues regarding immigration factored into the lead up to Bahamian independence in 1973 and well afterward. A West Indian immigrant voiced this concern in a 1967 letter to the editor of a daily newspaper, claiming that the "Beloved Premier promised a square deal for all Belongers" (p. 77). Tinker notes only that this was a resident status for non-Bahamians, and that "the term 'Expatriate' was used to describe whites, such as Europeans and North Americans, with similar immigrant status" (p. 77). In fact, the "Belonger" status was reserved for immigrants from other British colonial territories.

With this extensive history of legal and illegal immigration the Bahamian government deemed it imperative to determine who could qualify for Bahamian residence status or citizenship. Tinker notes that many Caribbean immigrants only intended to remain temporarily in the Bahamas before moving on to the United States, Canada, or the United Kingdom. British colonial immigration policy did not always consider local sentiment, especially from nonelite groups. Additionally, the Bahamas is nearby the two largest Caribbean islands which include the three most populous countries; one of these, Haiti, is the poorest country in the hemisphere. Unlike Cubans, whose country's politics allows them much easier access to the United States, Haitians are considered economic immigrants so migrating to the Bahamas not only provides economic opportunity but is often the most accessible path for many Haitians to eventually get to the United States.

Tinker tries to emphasize the specific contributions of Caribbean immigrants to the Bahamas. Yet his example of the influence of West Indian teachers is more perceived than real. Education and nursing were areas for which the colonial or Bahamian governments never contracted significant numbers of West Indians, the exception being Guyanese teachers 
hired in the 1980s. Tinker refers to West Indian teachers sent to Out Island schools in the 1950s and 196os but by this time these islands were sparsely populated because of internal migration to the capital island of New Providence or outside the country. Teacher training had long been neglected but a teacher training college was established on New Providence in the early 1960 .

Tinker makes an effort to identify issues regarding Caribbean migration to the Bahamas. The impact of this work would have been stronger if he had analyzed conditions within the Bahamas more closely. By not presenting a more dynamic perspective of Bahamian society, into which immigrants were accepted, he leaves readers with quite a stagnant view of the Bahamas as simply a "receiver society."

\section{Grace Turner}

Department of Anthropology, College of William and Mary

Williamsburg VA 23187, U.S.A.

gsturn@email.wm.edu

\section{Reference}

Marshall, Dawn, 1979. The Haitian Problem: Illegal Migration to the Bahamas. Kingston: Institute of Social and Economic Research, University of the West Indies. 